Article Type: Research Paper

\title{
Conservatism, Earnings Quality, and Stock Prices - Indonesian Evidence
}

\author{
Krismiaji $^{1 *}$ and Sururi ${ }^{2}$
}

\begin{abstract}
:
Research aims: This research investigates the association of conservatism (both conditional and unconditional) with quality of earnings as well as with stock prices on companies listed on the Indonesia Stock Exchange (IDX).

Design/Methodology/Approach: The research uses a sample of 846 observations of publicly listed companies on the Indonesian Stock Exchange for the fiscal year that ends on December 31, 2016 through 2018. Conditional conservatism is measured by using an asymmetric timeliness measure from Basu (ATMB). Net income ratio $(\mathrm{CFO} / \mathrm{NI})$ is a proxy for earnings quality whereas ratio between market value and book value (MTB) is a measure of unconditional conservatism. The data used in this study are obtained both from Indonesian Stock Exchange database, and from company annual reports.

Research findings: The study finds that all companies analyzed implement conservative accounting policies and practices. Besides, quality of earnings and stock prices are negatively associated with conditional conservatism. This research also proves that stock price negatively associated with unconditional conservatism, whereas unconditional conservatism does not associated with earnings quality.

Theoretical contribution/ Originality: This study enriches the existing literature about conservatism, especially in emerging market environment. Moreover, this study discusses a set of conservatism that consist of conditional and unconditional conservatism. This may give a complete picture of conservatism practices adopted by Indonesian companies.

Practitioner/Policy implication: Since conservatism can solve agency cost problems, the result of this study may affect the way a company produce useful information for interest parties.

Research limitation/Implication: The use of the purposive sampling method limits generalizations, because sample designs could not be assumed to characterize all companies listed on IDX.

Keywords: Conditional Conservatism; Unconditional Conservatism; ATMB
\end{abstract}

AFFILIATION:

${ }^{1,2}$ Accounting Academy of YKPN Yogyakarta, Special Region of

Yogyakarta, Indonesia

*CORRESPONDENCE:

xmiaji@gmail.com

THIS ARTICLE IS AVALILABLE IN:

http://journal.umy.ac.id/index.php/ai

DOI: 10.18196/jai.v22i1.9419

CITATION:

Krismiaji, K. \& Sururi, S. (2021). Conservatism, earnings quality, and stock prices - Indonesian evidence. Journal of Accounting and Investment, 22(1), 37-50.

\section{ARTICLE HISTORY}

Received:

22 July 2020

Revised:

01 Nov 2020

09 Nov 2020

Accepted:

01 Dec 2020

\section{Introduction}

This research is motivated by the condition that until now, conservatism is still an important accounting principle in the process of measuring earnings (Soliman \& Ragab, 2014), even though the conceptual framework, called prudence, is no longer included as element of both relevance and reliable (faithful representation) of accounting information. Conservatism is not included as an element of the quality of accounting information because conservatism is considered contrary to neutral principles (International Accounting Standards Board (IASB), 2018). 


\author{
Krismiaji \& Sururi \\ Conservatism, Earnings Quality, and Stock Prices - Indonesian Evidence
}

Based on that phenomenon, it is important to proof that conservatism or prudence is still one of important ingredients of earnings quality.

Earnings quality usually related to indicators, such as accrual quality, predictability, smoothness, persistency, timeliness, conservatism, and earnings uncertainties (Ahmed, 2020). Earnings are considered to have high quality if earnings is a predictor of sustainable earnings (future earnings). Therefore, if the financial reporting process does not produce sustainable earnings information, then the earnings are considered to be of poor quality. Extant research prove that financial reporting quality has a positive role on the firm's performance and the quality of decision making (Lin, Wang, \& Pan, 2016; Jaballah, Yousfi, \& Ali, 2014). While previous research commonly investigates the relevance (value relevance) and reliability (faithful representation) quality of accounting numbers, this study investigates conservatism and its association with earnings quality since earnings quality problems can arise if companies refer to conservatism consistently but they do not change their accounting policy (Ismail \& Elbolok, 2011). According to Chakrabarty and Moulton (2012), the conservatism principle is one of the most influential factors in accounting valuation.

Previous research has discussed conservatism, which is a method used to deal with uncertainty to protect creditors from efforts to distribute company assets as dividends. Accounting conservatism is an alternative effort to recognize profit or loss (Watts, 2003). Conservatism is a barrier to the disclosure good quality of accounting information and it provides guidelines for accountants in the process of choosing between two or more acceptable accounting methods. Preferred options are those that have the lowest value of assets and profits or the highest value of liabilities and costs. Therefore, conservatism directs accountants to be pessimistic when choosing accounting policies for financial reporting. Nevertheless, conservatism is beneficial for accounting information users. Watts (2003) aserts that the benefits of conservatism include: (1) contract motivation, (2) tax optimization, (3) litigation risk, and (4) asymmetry in the absence of regulatory functions.

This study uses conditional and unconditional conservatism introduced by Ball and Shivakumar (2005). Conditional conservatism is the use of policies and methods of accounting that realize losses on time compared to earnings. Conditional conservatism can also be interpreted as a profit that recognizes losses faster than gains (Beaver \& Ryan, 2005b). Unconditional conservatism is the implementation policies and methods of accounting that decrease net income and assets' book value without relating them to future economic events.

Previous studies report mixed results about the effect of conservatism on quality of earnings. Some report that conservatism has a positive effect on earnings (Francis, Hasan, \& Wu, 2013), and some report that conservatives harm earnings (Ball, Kothari, \& Nikolaev, 2013). This open an opportunity to further investigates the similar issues using two measure of conservatisme, conditional and aunconditional conservatism, and empoy observed data from different jurisdiction. This hopefully will enrich the conservatism literature. Such inconclusive research results confuse investors. If the 


\author{
Krismiaji \& Sururi \\ Conservatism, Earnings Quality, and Stock Prices - Indonesian Evidence
}

company makes more conservative accounting choices, the company faces a mismatch between current period earnings and future period costs, so earnings become less persistent because conservative accounting not only affects the quality of the accounting numbers reported in the statement of financial position but also affects the earnings quality disclosed in the statement of income. If the company adds their investment, conservative based accounting tends to report lower profits than actual profits, so there are an unclear existence and status of earings difference. This condition provides an opportunity and flexibility for companies to report greater profits in the future.

Most of the empirical research investigated the effect of conservatism on the quality of earnings and stock prices are carried out in developed capital markets, for example, Penman and Zhang (2002); Beaver and Ryan (2005a); and Hossein, Hossein, and Myysam (2010). Similar research carried out in the emerging capital markets is still small, if any, especially in Indonesia. This condition opens up opportunities to conduct similar research using data from public companies listed on the Indonesia Stock Exchange (IDX). Based on the conditions above, the research questions can be formulated as follows:

RQ: What is the impact of conservatism on earnings quality and stock prices on companies listed on the Indonesia Stock Exchange in 2016 to 2018?

The purpose of this study is to obtain empirical evidence about the association of conservatism on earnings quality and stock prices in Indonesian companies listed on the IDX or Indonesia Stock Exchange in 2016 to 2018. This study is different from previous studies. This study investigates simultaneously the effects of conditional conservatism and unconditional conservatism on the quality of earnings and stock prices in developing countries. Also, this study extends the asymmetry of the timeliness of earnings size by adding two ratios to the model, namely the ratio of operating cash flows to net income and market to book ratio, to assess the impact of conservatism on quality of earnings and stock prices.

Theoretically, this study enriches conservatism literature and suggest that conservatism is still an important and unique aspect of accounting information quality. Therefore, conservatisme principle or prudence needs to be considered and recognized as a part of financial quality ingredience in formal document. Practically, this study could help financial statement preparer in choosing for a set accounting policy choice, especially those which affect earning quality and future sock prices. Practically, given the important role of earnings and stock price for firm valuation and analysis, and that both conditionally and unconditionally conservative accounting choices are observable, our results should be of great interest for practitioners, especially investment analysts. Besides, the findings of this study would help Indonesian accounting standards setters to recommend accounting choices and policies that lead to high quality of earnings and provide financial reports that rationalize investors' decisions.

This manuscript is arranged systematically as follows. After outlining the introduction in the first part, this manuscript describes the study of literature and the development of 


\author{
Krismiaji \& Sururi \\ Conservatism, Earnings Quality, and Stock Prices - Indonesian Evidence
}

the hypothesis in part two. The third part describes the research method. This is followed by analysis and discussion of hypothesis testing in the fourth part. This manuscript is closed by presenting conclusions, suggestions, limitations, and further research opportunities in the future.

\title{
Literature Review and Hypotheses Development
}

Investors are very concerned about the quality of earnings. Therefore, investor concerns about earnings quality have steadily increased in recent years as many international companies announce non-actual profits and report temporary information as part of quarterly company reports. Investors are becoming more careful about company earnings information. Quality earnings are earnings that can be used by investors to predict abnormal earnings in the future (Ohlson \& Feltham, 1995). In other words, earnings quality can provide a real picture of the company today and a picture of the company's ability to survive in the future. Quality earnings can be proven by many company decisions made based on the earnings information (Dechow \& Dichev, 2002).

This study uses agency theory because conservatism is related to agency problems (Basu, 1997). Conservatism is used to overcome problems that arise between agents and principals. If the financial statements issued by an agent contain conservatism items, then Stockholders will choose to reduce managers' salaries because managers consider tending to prioritize their interest (Ball et al., 2013). To overcome this problem, management can choose to provide more conservative figures to show and prove that managers do not prioritize personal interests (Watts \& Zimmerman, 1983). This, when approved, can be released from legal responsibility (Givoly \& Hayn, 2000). This is supported by the results of research conducted by Hamdan, Abzakh, and Al-Ataibi (2011) who report that accounting conservatism can reduce agency costs and contributing to improve the quality of information whereas Kim, Kim, Kwon, and Lee (2015) state that accounting earnings presented conservatively will be more useful to reduce agency cost.

Conservatism is generally defined as the level of caution in assessing uncertain conditions with the purpose of assets or profits are not inflated and liability or costs are not lower reported. There are several more structured definitions of conservatism. Basu (1999) states that conservatism occurs when reported earnings recognize bad news faster than good news. Kothari (2000) stated that conservatism is a concept that delays the recognition of future cash inflows and it derives accountants to report the least numbers for revenues and assets and the utmost for expenses and liabilities. Based on current accounting standards, conservatism is applied to the measurement of assets as well as the recognition of income and expenses, while (Chen, Hemmer, \& Zhang, 2011) argue that conservatism tends to direct accountants to choose accounting methods that slow down the recognition of earnings and decrease the valuation of net assets.

Accounting conservatism can be categorized into two groups. Ball, Kothari, and Robin (2000) classify conservatism into conservatism in the income statement and statement 


\author{
Krismiaji \& Sururi \\ Conservatism, Earnings Quality, and Stock Prices - Indonesian Evidence
}

of financial position. Chandra (2011) distinguishes two types of conservatism as a conservatism that depends on news and the one that independent on news, whereas Ball and Shivakumar (2005) introduce the term of unconditional conservatism and conditional conservatism. This research uses Ball and Shivakumar version grouping. Yet, not much literature has investigated the relationship between both types of conservatism with stock prices and quality of earnings quality.

Penman and Zhang (2002) empirically report that conservative accounting can produce low-quality earnings. Previous studies performed by Chen, Folsom, Paek, and Sami (2014) and Abedini, Ranjbar, and Mozaffari (2014) report that accounting conservatism negatively associated with earnings quality and stock price, whereas Shafiei and Javaheri (2016) find negative relationship between conditional conservatism and earnings quality. Ismail and Elbolok (2011) repot that conditional conservatism negatively affects both earnings quality and stock prices of Egyptian firms while Nazaripur and Aghaei (2015) find that conditional conservatism negatively affects both earnings quality and stock prices of Iranian firms. Finally, Sari (2018) report that conditional conservatism negatively affects earnings quality. Bases on such previous studies, we formulate our first hypotheses as follows:

\title{
$\boldsymbol{H}_{1}$ : Earnings quality is negatively associated with conditional conservatism
}

Previous studies report a mix evidence for association between unconditional conservatism and quality of earnings. Ismail and Elbolok (2011) and Sari (2018) reports that unconditional conservatism does not affect earnings quality, whereas Rijneker (2016) concludes that conservative accounting affects the quality of information. Sanaa'nm (2016) reports that financial performance such as return on asset and earnings per Stock are positively affected by accounting conservatism. Finally, Aljaloudi (2018) reports that conservatism policy affect positively earnings quality. Mashoka, Adden, and Abuhommous (2018) report that earnings quality changes when conservatism levels change. Other studies prove that conservatism positively associated with cumulative stock returns in the financial crisis periods (Francis et al., 2013). The results support a theory which states that conservatism is an mechanism to effectivey reduce risk. Besides, Conservatism also reduces managers' incentives to manipulate earnings because the timeliness of recognizing losses in earnings reduces the impact of bad news on stock prices (Chen, Hemmer, \& Yun, 2007). Finally, Accounting conservatism is one of the mechanisms that deal with agency problems that protect the interests of investors (Lafond \& Roychowdhury, 2008). Based on this description, we formulate second hypotheses as follows:

\section{$\boldsymbol{H}_{2}$ : Earnings quality is positively related to unconditional conservatism}

Previous studies performed by Penman and Zhang (2002); Chen et al. (2014); and Abedini et al. (2014) report that accounting conservatism negatively associated with earnings quality and stock price. Moreover, Lyimo (2014) finds that conservatism do 


\author{
Krismiaji \& Sururi \\ Conservatism, Earnings Quality, and Stock Prices - Indonesian Evidence
}

affects stock prices. Other study suggests that conditional conservatism limits managers' incentive and ability to overstate performance and hide bad news from investors, which, in turn, reduces stock price crash risk (Kim \& Zhang, 2014). Moreover, Kousenidis, Ladas, and Negakis (2014) report a negative relation between conditional conservatism and future stock price crash risk whereas (Ismail \& Elbolok, 2011) and (Nazaripur \& Aghaei, 2015) find a negative effect of conditional conservatism on both stock price and quality of earnings. Finally, (Qian, Xian, \& Qiaoying, 2020) accounting conservatism, corporate governance and stock price collapse risk are negatively correlated. Based on this review, we formulate third hypotheses as follows:

$\boldsymbol{H}_{3}$ : Stock prices are negatively related to conditional conservatism.

Previous research report that conservatism positively associate with cumulative stock returns in a financial crisis periods (Francis et al., 2013). Zhu and Xia (2011) report a significant a positive association between accounting conservatism and cumulative abnormal returns, whereas Lyimo (2014) finds that conservatism do affects stock prices. Moreover, Shafiei and Javaheri (2016) find that conservatism positively associated with stock price and quality of earnings, whereas Nazaripur and Aghaei (2015) report insignificant association between unconditional conservatism and quality of earnings but report that it negatively affects stock prices of Iranian companies. Based on this review, we formulate fourth hypotheses as follows:

$\boldsymbol{H}_{4}$ : Stock prices are positively related to unconditional conservatism

\title{
Research Method
}

The data used in this research are companies listed on the Indonesia Stock Exchange (IDX) as the research population. The data are sourced from the annual report of companies, the database of IDX, and the website of companies. Samples were selected by non-probability method i.e. purposive sampling. To be selected, a sample should meet several criteria as follows: (1) selected companies are listed for the years of 20162018 consecutively on the IDX; (2) they should have complete data which is needed; (3) they are non included in the financial industry.

This study adopts the asymmetric timeliness measure of Basu (ATMB) to determine the conservatisms level. The main consideration is that this model considered being the most influential measurement (Wang, Hogrataigh, \& Zill, 2009). The second consideration is that previous research using this model tends to produce more consistent findings, so researchers consider this model more reliable. The third consideration is that it could explain the influence of the conditional adoption of conservatism on stock prices. ATMB model regress earnings on return to measure conditional conservatism. ATMB measures conservatism based on the faster effect of bad news on earnings than that of the good news. The news, both good and bad, are indicated by a sign on stock returns which is a proxy for economic news. In the ATMB, 
asymmetric timeliness become the conservatism function within a company. The timeliness difference between both bad news and good news is reflected by $\alpha_{3}$ in the regression model (1) as follows:

$$
\frac{E P S_{i t}}{P_{i t}}=\alpha_{0}+\alpha_{1} D R_{i t}+\alpha_{2} R E T_{i t}+\alpha_{3} D_{i t} * R E T_{i t}+\varepsilon_{i t}
$$

EPS $S_{i t}$ is the earnings per share of the company $i$ year $t, P_{i t}$ is the stock price of the company i year $t$, RETit is the return of Stocks of a company i year $t$, and DRit is a dummy variable. It worth 1 if $\mathrm{RET}_{\text {it }}$ is negative and it worth 0 if $R E T_{i t}$ is positive. The value of $\alpha_{3}$ will be greater than zero $\left(\alpha_{3}>0\right)$ when a company recognizes bad news earlier. However, ATMB does not only take into account the effect of conservatism on earnings quality, therefore researchers extend this measurement by including a variable that is the ratio between operating cash flow and net income (CFO/NI) as a proxy for quality of earnings, to test the effect of conservatism on quality of earnings, so equation (1) changes to equation (2) as follows:

$$
\frac{E P S_{i t}}{P_{i t}}=\alpha_{0}+\alpha_{1} D R_{i t}+\alpha_{2} R E T_{i t}+\alpha_{3} D_{i t}{ }^{*} R E T_{i t}+\alpha_{4} C F O_{i t} / N_{i t}+\varepsilon_{i t}
$$

The equation (2) is designed to assess conditional conservatism as well as to examine the association between stock prices and quality of earnings, therefore, the regression model 2 is expanded by including ratio of market value to book value (MTB) to measure unconditional conservatism, becoming equation (3) as follows.

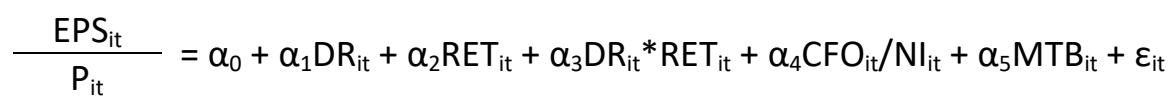

This model assumes that earnings reflect bad news faster than good news. In the ATMB, the greater asymmetric timeliness reflects the high level of conservatism. In regression equations, $\alpha_{3}$ is an asymmetric timeliness coefficient and is a key value of accounting conservatism. The value of $\alpha_{3}$ reflects the level of conditional conservatism. Also, this study regressed MTBit and DRit. The estimation coefficient for each company reflects the persistence portion of the variance between the book value and the market value of the company. Therefore, the value of this coefficient also reflects the level of practice of unconditional conservatism.

To test hypotheses, the models are extended become model 4, Model 5, Model 6, and Model 7 as follows:

$$
\begin{aligned}
& \text { EPS }_{\text {it }}=\alpha_{0}+\alpha_{1} \mathrm{DR}_{\mathrm{it}}+\alpha_{2} \mathrm{RET}_{\mathrm{it}}+\alpha_{3} \mathrm{DR}_{\mathrm{it}} * \mathrm{RET}_{\mathrm{it}}+\alpha_{4} \mathrm{CFO}_{\mathrm{it}} / \mathrm{Nl}_{\mathrm{it}}+\alpha_{5} \mathrm{CFO}_{\mathrm{it}} / \mathrm{Nl}_{\mathrm{it}} * \mathrm{DR}_{\mathrm{it}}+ \\
& P_{\text {it }} \quad \alpha_{6} \mathrm{CFO}_{\text {it }} / \mathrm{NI}_{\mathrm{it}} * \mathrm{RET}_{\mathrm{it}}+\alpha_{7} \mathrm{CFO}_{\mathrm{it}} / \mathrm{Nl}_{\mathrm{it}}{ }^{*} \mathrm{DR}_{\mathrm{it}} * \mathrm{RET}_{\mathrm{it}}+\varepsilon_{\mathrm{it}} \\
& \underline{E^{2} S_{i t}}=\alpha_{0}+\alpha_{1} D R_{i t}+\alpha_{2} R T_{i t}+\alpha_{3} D_{i t}{ }^{*} R E T_{i t}+\alpha_{4} P_{i t}+\alpha_{5} P_{i t}{ }^{*} D R_{i t}+\alpha_{6} P_{i t}{ }^{*} R E T_{i t}+ \\
& P_{\text {it }} \quad \alpha_{7} P_{i t}^{*}{ }^{*} R_{i t}{ }^{*} R E T_{i t}+\varepsilon_{i t} \\
& \frac{\mathrm{CFO}_{\text {it }}}{\mathrm{Nl}_{\text {it }}}=\alpha_{0}+\alpha_{1} \mathrm{DR}_{\mathrm{it}}+\alpha_{2} \mathrm{RET}_{\text {it }}+\alpha_{3} \mathrm{DR}_{\text {it }}{ }^{*} \mathrm{RET}_{\text {it }}+\alpha_{4} \mathrm{MTB}_{\text {it t }}+\varepsilon_{\text {it }}
\end{aligned}
$$




$$
P_{i t}=\alpha_{0}+\alpha_{1} D R_{i t}+\alpha_{2} R E T_{i t}+\alpha_{3} D R_{i t} * R_{E T} \text { it }+\alpha_{4} M_{T B} B_{i t}+\varepsilon_{i t}
$$

Hypotheses 1 is tested by Model 4 . It will be accepted if $\alpha_{7}$ in this model has positive sign and statistically significant. Hypotheses 2 is tested by Model 6 . It will be accepted if $\alpha_{4}$ in this model has positive sign and statistically significant. Hypotheses 3 is tested by Model 6. It will be accepted if $\alpha_{7}$ in this model has positive sign and statistically significant. Hypotheses 4 is tested by Model 7. Ite will be accepted if $\alpha_{4}$ in this model has positive sign and statistically significant.

\section{Result and Discussion}

From purposive sampling, this study gets 282 firms from 2016 through 2018, and the total observation is 846 firm-years. Table 1 presents descriptive statistics for the research variable. EPSP which is the ratio between earnings per Stock (EPS) and the mean of stock price is 0.04 . Stock price has minimum and maximum value of -1.14 and 0.62 respectively. RET which is stock return has a mean of -44.66 and it has minimum and maximum value of -90.042 and 27.275 respectively. This data implies that most of the sample firms have negative return and they potentially apply conservatism accounting in their financial reporting. This will be proved in the next regression analysis. CFO/NI, the earnings quality proxy, has score of 5.233.396, 232.712.239, and 583.844 for mean, maximum, and minimum respectively. This data imply that sample firms tend to have positive cashflow. MTB which the ratio between market and book value is a proxy of unconditional conservatism. This variable has values of 70.55 , 4.933.45, and 0.05 for mean, maximum, and minimum respectively. This data implies that the market value of the sample firms on average greater than their book value.

Table 1 Descriptive Statistics

\begin{tabular}{lcccc} 
& Minimum & Maximum & Mean & Std. Deviation \\
\hline EPSP & $(1.14)$ & 0.62 & 0.04 & 0.23 \\
RET & $(90,042.30)$ & $27,575.00$ & $(44.66)$ & $11,923.62$ \\
DR & - & 1.00 & 0.45 & 0.50 \\
CF/ONI & $(583,844.38)$ & $232,712,339.07$ & $5,233,396.44$ & $26,844,824.74$ \\
MTB & 0.05 & $4,935.45$ & 70.55 & 569.43 \\
DR*RET & $(90,042.30)$ & 581.00 & $(2,122.18)$ & $10,507.02$ \\
\hline
\end{tabular}

Table 2 present the correlation among variables. The result shows that the value of coefficient correlation between variables is small. This indicates that there is no multicollinearity. The correlation between CFONI and EPSP is -0.008 whereas the correlation between MTB and SPSP is 0.008 . Although such correlation is not significant, these are the initial indication of the association among variables of interests. This will be further investigated by multiple regression in hypothesis testing. 
Table 2 Bivariate Correlations

\begin{tabular}{lccccc} 
& EPSP & RET & DR & CF/ONI & MTB \\
\hline RET & .009 & & & & \\
DR & -.123 & $-.356^{* *}$ & & & \\
CF/ONI & -.008 & -.003 & .122 & & \\
MTB & .008 & .170 & -.110 & -.017 & \\
DR*RET & .006 & $.917^{* *}$ & -.223 & .027 & .022 \\
\hline
\end{tabular}

**. Correlation is significant at the 0.01 level (2-tailed)

This research uses multiple regression analysis to test hypotheses. The parameter of the model is calculated by regenerating EPS as the dependent variable, which indicates more timely information for companies with bad news, resulting in higher $\mathrm{R}^{2}$ predictions for the companies in the sample. The $\alpha_{3}$ coefficient is estimeted to be higher for bad news since earnings are expected to be less sensitive to positive returns than negative returns. Panel $(A)$ in Table 3 shows the results of the cross-sectional regression of all sample companies. The regression results show that the return coefficient $\left(\alpha_{3}\right)$ is 0.122 and significant at the level of $1 \%$. This result indicates that firms use conservatism in financial reporting, and thus the firms are feasible for testing the hypotheses.

Table 3 Results of Cross-Sectional Regression Analysis

\begin{tabular}{|c|c|c|c|c|c|c|}
\hline $\mathrm{EPS}_{\mathrm{it}=}=\alpha_{0}+\alpha$ & ${ }_{2} \mathrm{RET}_{\text {it }}$ & $+\alpha_{3} D R_{i t}{ }^{*} R E 1$ & & & & (1) \\
\hline $\mathbf{P}_{\mathrm{it}}$ & & & & & & \\
\hline Panel A & & & & & & \\
\hline & $\alpha_{0}$ & $\alpha_{1}$ & $\alpha_{2}$ & $\alpha_{3}$ & $R^{2}$ & Adj. $R^{2}$ \\
\hline & 0.03 & -0.077 & 0.033 & 0.122 & $40.94 \%$ & $38.45 \%$ \\
\hline & 1 & & & & & \\
\hline Panel B & & & & & & \\
\hline & & $\begin{array}{l}\text { Companies } \\
\text { positive ret }\end{array}$ & & & $\begin{array}{l}\text { oanies with } \\
\text { tive returns }\end{array}$ & \\
\hline Adjusted $\mathrm{R}^{2}$ & & $1.60 \%$ & & & $2.21 \%$ & \\
\hline Observations & & 402 & & & 444 & \\
\hline
\end{tabular}

Panel (B) in Table 3 presents the classification of firm-years data into two groups, namely bad news companies and good news companies based on negative or positive return (RET) numbers, thus the DR dummy variable will be 1 if RET is negative and 0 if RET is positive. Dummy variables record the effect of intercept and sample slope with negative returns. The coefficient of the interaction variable, $\alpha_{3}$, which measures the difference in earnings sensitivity to positive and negative returns has a significant value. This indicates that earnings are responsive to negative returns of 4.69 times [ $(0.033+$ 0.122 ) / 0.033] than the level of sensitivity to positive returns. The adj. $R^{2}$ value derived from the separation of the two sample groups (negative returns and positive returns) shows that the explanatory power of groups of companies with negative returns $(2.21 \%$; 198 companies) is greater than companies with positive returns (1.60\%; 184 companies).

The hypotheses are tested by Model 4, Model 5, Model 6, and Model 7 which are the extension of Model 2 and Model 3. The results are presented in Table 4. Hypothesis 1 states that earnings quality is negatively related to conditional conservatism, using the operating cash flow and net income ratio (CFO/NI). The results of this study, stated in 
column Model 4 in Table 4 show that coefficient of $\alpha_{7}$ is -0.322 and this significant at $1 \%$ level. This outcome implies that conditional conservatism negatively affects earnings quality. Thus, hypothesis 1 is supported by empirical research data. These results confirm previous research conducted by Penman and Zhang (2002) and Ball et al. (2013) which states that conservative accounting produces low-quality earnings. In some extent, this result is also in line with the findings of Rijneker (2016) who concludes that conservative accounting affects the quality of information; Shaqqour (2017) who report that conservatism accounting negatively affects financial reporting, and Dutta and Patatoukas (2017) report that conditionally conservative accruals lead to the higher variance of bad news accruals than the variance of good news accruals.

Table 4 Regression Analysis

\begin{tabular}{|c|c|c|c|c|c|c|c|c|}
\hline & \multicolumn{2}{|c|}{ Model 4} & \multicolumn{2}{|c|}{ Model 5} & \multicolumn{2}{|c|}{ Model 6} & \multicolumn{2}{|l|}{ Model 7} \\
\hline Variable & Coeffic & & Coeffic & ent & Coefficie & & Coefficier & \\
\hline Intercept & 0.057 & $* * *$ & 0.049 & $* * *$ & 188.543 & $* * *$ & 2301.328 & $* * *$ \\
\hline RET & -0.106 & $* * *$ & 0.208 & & -96.821 & $* * *$ & 2.723 & $* * *$ \\
\hline DR & 0.002 & & 0.005 & & 545.525 & & 621.171 & \\
\hline DR*RET & 0.061 & $* * *$ & 0.069 & & 105.594 & $* * *$ & -2.976 & $* * *$ \\
\hline CFO/NI & -0.255 & $* *$ & & & & & & \\
\hline CFO/NI*RET & -0.103 & & & & & & & \\
\hline CFO/NI*DR & 0.894 & & & & & & & \\
\hline CFO/NI*DR*RET & -0.322 & $* * *$ & & & & & & \\
\hline $\mathrm{P}$ & & & -0.678 & $* * *$ & & & & \\
\hline $\mathrm{P} * \mathrm{RET}$ & & & -0.633 & & & & & \\
\hline$P * D R$ & & & -0.296 & & & & & \\
\hline $\mathrm{P} * \mathrm{DR} * \mathrm{RET}$ & & & -0.452 & $* * *$ & & & & \\
\hline MTB & & & & & 276.981 & $* * *$ & -5.774 & $* * *$ \\
\hline Adj. $R^{2}$ & 0.118 & & 0.130 & & 0.259 & & 0.088 & \\
\hline F-statistic & 2.421 & $* * *$ & 2.581 & $* *$ & 14.924 & $* *$ & 145.818 & $* * *$ \\
\hline
\end{tabular}

$* * *, * *$, and $*$ : significant at the level of $1 \%, 5 \%$, and $10 \%$ respectively

Hypothesis 2 states that earnings quality is positively related to unconditional conservatism. The results of statistical analysis are presented on column Model 6 in Table 4 which indicates that coefficient of $\alpha 4$ is 276.981 and it is significant at $1 \%$ level. This caculation implies that unconditional conservatism affects earnings quality positively. Thus, the second hypothesis is confirmed by research data. This result is also confirmed Beaver and Ryan (2005a) who prove that with unconditional conservatism, the net book value of assets decreases because of some predetermined factor of the accounting process, Francis et al. (2013), who report a positive relationship between conservatism and cumulative stock returns; Zhu and Xia (2011) who disclose a positive relationship between accounting conservatism and cumulative abnormal; and Mashoka et al. (2018) who report that earnings quality changes when conservatism levels changes.

Hypothesis 3 predicts that stock prices are negatively related to conditional conservatism. The result of the statistical analysis Model 5 shows that coefficient of $\alpha 7$ is -0.452 and it significant at $1 \%$ level. It implies that conditional conservatism negatively 


\author{
Krismiaji \& Sururi \\ Conservatism, Earnings Quality, and Stock Prices - Indonesian Evidence
}

affects stock price. Thus, the third hypothesis stating that stock prices are negatively related to conditional conservatism is supported by empirical data, so this hypothesis is accepted. These results confirm previous research conducted by Jing (2007). His research proves that earnings quality and stock price negatively associated. It also confirmed by Hossein et al. (2010) who find that tiered prices in conservative earnings are smaller than tiered prices in less conservative earnings.

Hypothesis 4 predicts that stock prices are positively related to unconditional conservatism. The results, presented in Tabel 4 column Model 7, indicates that coefficient of $\alpha 4$ is -5.774 and significant at $1 \%$. This means that the adoption of unconditional conservatism policies negatively affects stock prices. Thus, this hypothesis is not confirmed by research data, so it is rejected. Unconditional conservatism is the implementation of accounting policies and methods reducing book value of asset and net income without relating them to future economic events. The result means that when unconditional conservatism policy increase, the Stock price decrease, and vice versa. We suspect that the conservatism policy is not fully disclosed in the financial reporting. Another possibility is that such a policy is not well understood by investors. Therefore, investors simply interpreted that when a firm report asset and or profit in the lower value, they respond to it as the problem for the company. This is the main reason why conservatism is often said to be a barrier to the reporting of faithful representation and relevant financial accounting information.

\title{
Conclusion
}

This research investigates the impact of both conditional conservatism and unconditional conservatism practices on stock prices and earnings quality on a sample of companies listed on the Indonesia Stock Exchange for the period 2014 to 2018. The main conclusions of this study are that: (1) all companies that are analyzed apply policies and conservative accounting practices, (2) stock price and earnings quality are negatively associated with conditional conservatism, (3) unconditional conservatism and earnings quality are positively associated, and (4) unconditional conservatism and stock prices are negatively associated. These results provide a discourse for policymakers in Indonesia to increasi the financial reporting integrity using accounting methods that take into account earnings quality and reflect stock prices on the capital market.

This research has limitations. First, the use of the purposive sampling method limits generalizations, because sample designs cannot be asserted to show all companies listed on IDX. Second, the instrument operated to calculate both conditional and unconditional conservatism, on the basis of its capacity to measure two types of conservatism. Therefore, it is necessary to carry out further research in the future by considering other factors that might influence conservatism such as environmental factors, cultural factors, company size, and industry type. The research can be performed using a larger sample of listed companies to examine the association between conditional conservatism and unconditional conservatism on a wide range of 


\author{
Krismiaji \& Sururi \\ Conservatism, Earnings Quality, and Stock Prices - Indonesian Evidence
}

variables such as earnings quality, stock prices, company valuations, capital costs, and corporate governance mechanisms.

\title{
References
}

Abedini, B., Ranjbar, M. H., \& Mozaffari, A. (2014). Investigating effect of accounting conservatism and earning quality on reaction of investors to cash stocks of companies accepted in Tehran Stock Exchange. International Journal of Academic Research in Accounting, Finance and Management Sciences, 4(1), 331-339. https://doi.org/10.6007/ijarafms/v4-i1/656

Ahmed, I. E. (2020). The qualitative characteristics of accounting information, earnings quality, and Islamic banking performance: Evidence from the gulf banking sector. International Journal of Financial Studies, 8(30), 1-16. https://doi.org/doi:10.3390/ijfs8020030w

Aljaloudi, H. O. (2018). The impact of conservatism policy on reporting quality in Jordanian banks sector. Journal of Finance and Accounting, 6(3), 91-95. https://doi.org/10.11648/i.jfa.20180603.12

Ball, R., \& Shivakumar, L. (2005). Earnings quality in UK private firms: Comparative loss recognition timeliness. Journal of Accounting and Economics, 39(1), 83-128. https://doi.org/10.1016/i.jacceco.2004.04.001

Ball, R., Kothari, S. P., \& Nikolaev, V. V. (2013). Econometrics of the basu asymmetric timeliness coefficient and accounting conservatism. Journal of Accounting Research, 51(5), 1071-1097. https://doi.org/10.1111/1475-679X.12026

Ball, R., Kothari, S. P., \& Robin, A. (2000). The effect of international institutional factors on properties of accounting earnings. Journal of Accounting \& Economics, 29(1), 1-51. https://doi.org/10.1016/S0165-4101(00)00012-4

Basu, S. (1997). The conservatism principle and the asymmetric timeliness of earnings 1. Journal of Accounting and Economics, 24(1), 3-37. https://doi.org/10.1016/S01654101(97)00014-1

Basu, S. (1999). Discussion of international differences in the timeliness, conservatism, and classification of earnings. Journal of Accounting Research, 37, 89-99. https://doi.org/10.2307/2491346

Beaver, W. H., \& Ryan, S. G. (2005a). Conditional and unconditional conservatism: concepts and modeling. Review of Accounting Studies, 10(2-3), 269-309. https://doi.org/10.1007/s11142-005-1532-6

Beaver, W. H., \& Ryan, S. G. (2005b). Discussion of conditional and unconditional conservatism: Concepts and modeling. Review of Accounting Studies, 10, 269-309. https://doi.org/10.1007/s11142-005-1533-5

Chakrabarty, B., \& Moulton, P. C. (2012). Earnings announcements and attention constraints: The role of market design. Journal of Accounting and Economics, 53(3), 612634. https://doi.org/10.1016/i.jacceco.2012.01.001

Chandra, U. (2011). Income conservatism in the U.S. technology sector. Accounting Horizons, 25(2), 285-314. https://doi.org/10.2308/acch-10022

Chen, L. H., Folsom, D. M., Paek, W., \& Sami, H. (2014). Accounting conservatism, earnings persistence, and pricing multiples on earnings. Accounting Horizons, 28(2), 233-260. https://doi.org/10.2308/acch-50664

Chen, Q., Hemmer, T., \& Yun, Z. (2007). On the relation between conservatism in accounting standards and incentives for earnings management. Journal of Accounting Research, 45(3), 541-565. https://doi.org/10.1111/j.1475-679X.2007.00243.x 


\section{Krismiaji \& Sururi \\ Conservatism, Earnings Quality, and Stock Prices - Indonesian Evidence}

Chen, Q., Hemmer, T., \& Zhang, Y. (2011). Optimal conservative accounting. SSRN Electronic Journal. https://doi.org/10.2139/ssm.591306

Dechow, P. M., \& Dichev, I. D. (2002). The quality of accruals and earnings: The role of accrual estimation errors. The Accounting Review, 77(1), 35-59. Retrieved from https://www.jstor.org/stable/3203324

Dutta, S., \& Patatoukas, P. N. (2017). Identifying conditional conservatism in financial accounting data: Theory and evidence. The Accounting Review, 92(4), 191-216. https://doi.org/10.2308/accr-51640

Francis, B., Hasan, I., \& Wu, Q. (2013). The benefits of conservative accounting to shareholders: Evidence from the financial crisis. Accounting Horizons, 27(2), 319-346. https://doi.org/10.2308/acch-50431

Givoly, D., \& Hayn, C. (2000). The changing time-series properties of earnings, cash flows and accruals: Has financial reporting become more conservative? Journal of Accounting and Economics, 29(3), 287-320. https://doi.org/10.1016/S0165-4101(00)00024-0

Hamdan, A. M., Abzakh, M. H., \& Al-Ataibi, M. H. (2011). Factors influencing the level of accounting conservatism in the financial statements. International Business Research, 4(3), 145-155. https://doi.org/10.5539/ibr.v4n3p145

Hossein, G., Hossein, M., \& Myysam, H. (2010). Accounting conservatism, earnings persistence, and pricing multiples on earnings. Journal of Accounting Knowledge, 1(2), 55-73. Retrieved from https://www.sid.ir/en/journal/JournalList.aspx?ID=13168

Ismail, T. H., \& Elbolok, R. M. (2011). Do conditional and unconditional conservatism impact earnings quality and stock prices in Egypt? Research Journal of Finance and Accounting, 2(12), 7-22. Retrieved from https://iiste.org/Journals/index.php/RJFA/article/view/1293

Jaballah, E., Yousfi, W., \& Ali, Z. M. (2014). Quality of financial reports: Evidence from the Tunisian firms. Journal of Business Management and Economics, 5(2), 30-38. Retrieved from https://ideas.repec.org/a/etr/series/v5y2014i02p030-038.html

Jing, Z. (2007). Earnings quality, analysts, institutional investors, and stock price synchronicity. Dissertation. Hong Kong Polytechnic University.

Kim, J., \& Zhang, L. (2014). Accounting conservatism and stock price crash risk: firm level evidence. Contemporary Accounting Research, 33(1), 412 - 441. https://doi.org/https://doi.org/10.1111/1911-3846.12112

Kim, Y. J., Kim, J. H., Kwon, S., \& Lee, S. J. (2015). Percent accruals and the accrual anomaly: Korean evidence. Pacific Basin Finance Journal, 35(1), 340-366. https://doi.org/doi:10.1016/i.pacfin.2015.02.006

Kothari, S. P. (2000). Capital markets research in accounting. JAE Rochester Conference. https://dx.doi.org/10.2139/ssrn. 235798

Kousenidis, D. V., Ladas, A. C., \& Negakis, C. I. (2014). Accounting conservatism quality of accounting information and crash risk of stock prices. The Journal of Economic Asymmetries, 11(1), 120-137. https://doi.org/https://doi.org/10.1016/j.jeca.2014.09.001

Lafond, R., \& Roychowdhury, S. (2008). Managerial ownership and accounting conservatism. Journal of Accounting Research, 46(1), 101-135. https://doi.org/10.1111/i.1475679X.2008.00268.x

Lin, C.-J., Wang, T., \& Pan, C.-J. (2016). Financial reporting quality and investment decisions for family firms. Asia Pacific Journal of Management, 33(2), 499-532. https://doi.org/10.1007/s10490-015-9438-8

Lyimo. (2014). Conditional conservatism and its effect on earnings quality and stock prices in Indian capital market. European Journal of Business and Management, 6(22), 98-104. 


\section{Krismiaji \& Sururi \\ Conservatism, Earnings Quality, and Stock Prices - Indonesian Evidence}

Retrieved from

https://www.iiste.org/Journals/index.php/EJBM/article/view/14459

Mashoka, T., Adden, A., \& Abuhommous, A. (2018). The effect of conservatism on earnings quality. Jordan Journal of Business Administration, 14(1), 165-175. Retrieved from https://journals.ju.edu.jo/JJBA/index

Nazaripur, M., \& Aghaei, H. (2015). The impact of conditional and unconditional conservatism on the earning quality and stock prices. International Journal of Computer Technology and Applications, 6(1), 1-20. Retrieved from https://www.ijcta.com/vol6issue1.php

Ohlson, J. A., \& Feltham, G. A. (1995). Valuation and clean surplus accounting for operating and financial activities. Contemporary Accounting Research, 11(2), 689-731. Retrieved from https://cpb-usw2.wpmucdn.com/u.osu.edu/dist/7/36891/files/2017/07/Feltham19951 kngbiq.pdf

Penman, S. H., \& Zhang, X. J. (2002). Accounting conservatism, the quality of earnings, and stock returns. The Accounting Review, 77(2), 237-264. https://doi.org/10.2308/accr.2002.77.2.237

Qian, W., Xian, L., \& Qiaoying, L. (2020). Empirical research of accounting conservatism, corporate governance and stock price collapse risk based on panel data model. Connection Science, 20(1), 1-6. https://doi.org/10.1080/09540091.2020.1806204

Rijneker, S. (2016). The effect of accounting conservatism on information quality in financial reporting. Master Thesis. University of Amsterdam.

Sanaa'nm. (2016). The effect of accounting conservatism on financial performance indicators in the Jordanian insurance companies. Journal of Internet Banking and Commerce, 2(1), 116. Retrieved from https://www.icommercecentral.com/open-access/the-effect-ofaccounting-conservatism-on-financial-performance-indicators-in-the-jordanianinsurance-companies.php?aid $=67482$

Sari, R. D. (2018). Pengaruh konservatisme conditional dan unconditional terhadap kualitas laba. Working Paper. Universitas Negeri Padang.

Shafiei, M., \& Javaheri, B. (2016). Investigating the relationship between accounting conservatism on earnings quality and stock price in corporations of accepted in Tehran stock exchange. International Journal of Humanities and Cultural Studies, April(Special Issue), 109-1101. Retrieved from https://www.ijhcs.com/index.php/ijhcs/article/view/1204

Shaqqour, O. F. (2017). The role of accounting conservatism in financial reporting in reducing the practice of earnings management in Jordanian extractive companies. Journal of Business \& Management, 4(3), 110-129. https://doi.org/10.25255/jbm.2016.4.3.110.129

Wang, R. Z., Hogrataigh, C. O., \& Zill, T. Z. (2009). Measures of accounting conservatism: A construct validity perspective. Journal of Accounting Literature, 28, 165-203. Retrieved from https://www.journals.elsevier.com/journal-of-accounting-literature

Watts, R. L. (2003). Conservatism in accounting part II: Evidence and research opportunities. Accounting Horizons, 17(2), 287-301. https://doi.org/10.2308/acch.2003.17.4.287

Watts, R., \& Zimmerman, J. (1983). Agency problems, auditing, and the theory of the firm: Some evidence. Journal of Law and Economics, 26(3), 613-633. https://doi.org/10.1086/467051

Zhu, S., \& Xia, D. (2011). Accounting conservatism and stock pricing: an analysis based on China's split-stock reform. Nankai Business Review International, 2(1), 23-47. https://doi.org/10.1108/20408741111113484 